\title{
PUMPS FOR THE ACTION ON THE EUROPEAN UNION IN THE SCOPE OF THE EUROPEAN AGENDA ON SECURITY
}

\author{
Marin Petkov ${ }^{1}$ and Dragomir Krastev ${ }^{2}$ \\ ${ }^{1}$ Assoc. Professor, Ph.D., National Military University, Veliko Tarnovo, Bulgaria, \\ marin_5kov@abv.bg \\ ${ }^{2}$ Assoc. Professor, Ph.D., National Military University, Veliko Tarnovo, Bulgaria, \\ drago.krastev@gmail.com
}

\begin{abstract}
The European Union aims to ensure that people live in an area of freedom, security and justice, without internal boundaries. Europeans need to feel confident that, wherever they move within Europe, their freedom and their security are well protected, in full compliance with the Union's values, including the rule of law and fundamental rights. In recent years new and complex threats have emerged highlighting the need for further synergies and closer cooperation at all levels. Many of today's security concerns originate from instability in the EU's immediate neighbourhood and changing forms of radicalisation, violence and terrorism. Threats are becoming more variable and more international, as well as increasingly cross-border and cross-sectorial in nature. These threats require an effective and coordinated response at European level. All the EU institutions have agreed that we need a renewed Internal Security Strategy for the coming five years.
\end{abstract}

Keywords: European Union, agenda, security.

\section{INTRODUCTION}

The European Union aims to ensure that people live in an area of freedom, security and justice, without internal boundaries. Europeans need to feel confident that, wherever they move within Europe, their freedom and their security are well protected, in full compliance with the Union's values, including the rule of law and fundamental rights. In recent years new and complex threats have emerged highlighting the need for further synergies and closer cooperation at all levels. Many of today's security concerns originate from instability in the EU's immediate neighbourhood and changing forms of radicalisation, violence and terrorism. Threats are becoming more variable and more international, as well as increasingly cross-border and cross-sectorial in nature.

\section{PUMPS FOR THE ACTION ON THE EUROPEAN UNION IN THE SCOPE OF THE EUROPEAN AGENDA ON SECURITY}

\section{Better information exchange}

The Schengen Information System (SIS) is the most widely used information-sharing instrument today. Competent national authorities can use it to consult alerts on wanted or missing persons and objects, both inside the Union and at the external border. The SIS was upgraded in early 2015 to improve information 
exchange on terrorist suspects and to reinforce the efforts of Member States to invalidate the travel documents of persons suspected of wanting to join terrorist groups outside the EU. To further strengthen security at the external borders, there should be fuller use of the SIS together with Interpol's database on Stolen and Lost Travel Documents (SLTD). The Commission will help Member States to use automated border controls with checks of the SIS and the SLTD, and it will continue to monitor if Member States implement their obligation to provide data to the SLTD.

Complementary measures to improve security in relation to the movement of goods also contribute to tackle illegal activities at the border, such as trafficking of weapons, illicit drug and cigarette smuggling or illegal currency transfers. The Customs Advance Cargo Information System provides customs authorities with advance notification for security risk assessment of cargo arriving into and departing from the EU. This system should be fully exploited by ensuring effective sharing of information between customs and with other law enforcement authorities. The Anti-Fraud Information System (AFIS) provides a crucial platform for exchange of customs anti-fraud information supporting customs law enforcement to fight cross border crime.

The Prüm framework is another example of an information exchange tool at EU level that is yet to be used to its full potential. It can offer automated comparison of DNA profiles, fingerprint data and vehicle registration data - which are key to detecting crime and building an effective case. The system is falling short of its potential because at this stage only a limited number of Member States have implemented their legal obligations and integrated the network with their own systems. This impedes the overall effectiveness of the Prüm framework in catching and prosecuting criminals. Member States have received significant financial and technical support for implementation. The Commission will treat this area as a priority in using its powers to ensure the correct implementation of EU law.

Of course, legal implementation of EU instruments at national level is not enough. The tools of the EU security framework will only take full effect when national law enforcement agencies feel confident in existing instruments and share information readily. The proposal for a new legal basis for Europol, 15 currently before the colegislators, seeks to enhance Europol's analytical capabilities, trigger operational action on the part of Member States, and reinforce the agency's data protection regime. Member States should use Europol as their channel of first choice for law enforcement information sharing across the EU. Europol's Secure Information Exchange Network Application (SIENA) allows Member States to exchange information in a swift, secure and user-friendly way with each other, with Europol, or with third parties that have a cooperation agreement with Europol. The active use of information exchange instruments also needs the right interface between the EU's tools and national law enforcement systems, such as Single Points of Contact. Member States must put the right structures in place at national level to integrate and coordinate the work of the relevant authorities.

Increased operational cooperation

The Lisbon Treaty provides legal and practical arrangements to make operational cooperation between authorities of different Member States effective. Through the EU Policy Cycle for serious and organised crime, Member States authorities coordinate common priorities and operational actions. The Standing Committee on Operational Cooperation on Internal Security (COSI) plays a central role. The Policy Cycle provides a methodology for an intelligence-led approach to internal security, based on joint threat assessments coordinated within Europol. It targets available resources in view of immediate, mid-term and long-term security threats and risks. The Policy Cycle should be used more by Member States to launch concrete law enforcement operations to tackle organised crime, including with third countries. Operation Archimedes, coordinated by Europol in September 2014 to address a variety of serious crimes across Member States and third countries, provided a practical example of how this can help.19 Such operations should be evaluated regularly in order to identify best practices for future action. EU agencies play a crucial role in supporting operational cooperation. They contribute to the assessment of common security threats, they help to define common priorities for operational action, and they facilitate cross-border cooperation and prosecution. Member States should make full use of the support of the agencies to tackle crime through joint action. Increased cooperation between the agencies should also be promoted, within their respective mandates. The revised cooperation agreement between Europol and Frontex, once implemented, will allow such synergies by enabling the two agencies to share personal data with appropriate data protection safeguards. Eurojust and Europol should further enhance their operational cooperation.

Supporting action: training, funding, research and innovation

In addition to information exchange and operational cooperation, the EU provides support to security-related actions through training, funding and the promotion of security-related research and innovation. The Commission seeks to target this support in a strategic and cost-effective way. 
The effectiveness of cooperation tools relies on law enforcement officers in Member States knowing how to use them. Training is essential to allow authorities on the ground to exploit the tools in an operational situation. The European police college CEPOL organises courses, defines common curricula on crossborder cooperation and coordinates exchange programmes. The current legislative proposal on CEPOL would further reinforce its ability to prepare police officers to cooperate effectively and to develop a common law enforcement culture.26 CEPOL should adapt its yearly training programmes to the priorities set out in this Agenda. National police academies should also use EU funding to make cross-border cooperation an integral part of their own training and practical exercises. Training for the judiciary and judicial staff should also be better aligned with EU priorities, building on existing structures and networks and with the support of the European Judicial Training Network (EJTN) and of the European e-Justice Portal and e-learning.

The recently created Internal Security Fund provides a responsive and flexible tool to address the most crucial challenges up to 2020. This Agenda provides strategic direction for the Fund, with a focus on those areas where financial support will bring most value added. Priority uses of the fund should include updating national sections of the Schengen Information System, implementing the Prüm framework and setting up Single Points of Contact. The Fund should also be used to strengthen cross-border operational cooperation under the EU Policy Cycle for serious and organised crime, and to develop 'exit strategies' for radicalised persons with the help of best practices exchanged in the Radicalisation Awareness Network. Other EU funding instruments, such as Horizon 2020 for research and innovation27, the European Structural and Investment Funds, the EU Justice Programmes, the Customs 2020 Programme and financial instruments for external action can also contribute, in their respective areas, to support the priorities of the Agenda on Security. The mid-term review of the Internal Security Fund in 2018 will provide an opportunity to take stock of how funding has helped to deliver the priorities of the Agenda and reprioritise as necessary.

A competitive EU security industry can also contribute to the EU's autonomy in meeting security needs. The EU has encouraged the development of innovative security solutions, for example through standards and common certificates. The Commission is considering further action, such as on alarm systems and airport screening equipment, to remove barriers to the Single Market and to enhance the competitiveness of the EU security industry in export markets. Forensic science is critical to law enforcement and prosecution. Law enforcement and judicial authorities must be confident that the forensic data they rely on is of high quality, including if the data comes from another Member State. It is therefore important to ensure that the forensic data exchanged through information exchange systems, such as the Prüm framework for fingerprints and DNA profiles, can be effectively used in court. A European Forensic Area, to align the processes of forensic service providers in Member States, would foster cooperation and ensure confidence.

\section{CONCLUSION}

Security should be a key priority in a wide range of funding instruments, research and innovation programmes as well as training initiatives. Existing priorities should be adjusted as required.

The European Agenda on Security sets out the actions necessary to deliver a high level of internal security in the EU. It must be a shared agenda. Its successful implementation depends on the political commitment of all actors concerned to do more and to work better together. This includes EU institutions, Member States and EU agencies. It requires a global perspective with security as one of our main external priorities. The EU must be able to react to unexpected events, seize new opportunities and anticipate and adapt to future trends and security risks (Hristov, 2018a, pp.61-67; Hristov, Radulov, lliev, Andreeva, 2010a; Hristov, 2018b, pp. 183-186; Hristov, Ninov, 2018c, pp.316-323; Hristov, Naplatanova, 2018d, pp. 293-315; Hristov, 2017a, pp. 998-1004, Hristov, Georgiev, 2017b, , pp. 110 -113; Hristov, Georgiev, 2017c, , pp. 114-117; Hristov, Glushkov, 2018e, pp.582-588; Hristov, Glushkov, 2018f, pp. 187-193; Hristov, 2017d, pp. 821-829; Madanski, Georgiev, 2017e, pp. 4-13; Madanski, Georgiev, 2017f, pp. 43-51; Terziev, Madanski, Georgiev, 2017g pp. 748-753; Terziev, Madanski, Georgiev, 2017h pp. 743-747; Terziev, Madanski, Georgiev, 2017i pp. 923-927; Terziev, Madanski, Georgiev, 2017j, pp. 1051-1055; Terziev, Nichev, Bankov, 2016a, s.189196; Terziev, Nichev, Bankov, 2016b, s. s.116-134; Terziev, Nichev, Bankov, 2016c, pp.12-21; Terziev, Nichev, Bankov, 2016d, str.119-128; Terziev, Nichev, Bankov, 2016e, str.129-146; Terziev, Nichev, Bankov, 2016e, str.129-146; Terziev, Nichev, Bankov, 2016f, str. 144-185; Terziev, Nichev, Bankov, 2016f, str. 144185; Terziev, Nichev, Bankov, 2016g, s.413-422; Terziev, Nichev, Bankov, 2016h, str.177-204; Nichev, 2017k, str. 121-128; Nichev, 2017l, pp. 129-135; Kanev, Terziev. 2017m; Kanev, Terziev, 2017n; Terziev, 2017o; Terziev, 2016i; Terziev, 2017p; Terziev, 2017q; Terziev, Vezieva, Arabska, 2016j; Terziev, Manolov, 2016k; Terziev, Minev, Sotirov, Ivanov, 2016I; Terziev, Kanev, 2017r; Terziev, Madanski, 2017s; Terziev, Madanski, 2017t; Terziev, Madanski, 2017u; Terziev, Madanski, Kanev, 2017v; Terziev, Madanski, Kanev, 2017w; Terziev, Madanski, Kanev, 2017x; Terziev, Madanski, Kanev, 2017y; Terziev, Madanski, Kanev, 2017z; Terziev, Nichev, 2016m; Terziev, Nichev, 2017). 


\section{REFERENCE LIST}

Hristov, Neno. (2018a). Military Education as Possibility in Bulgaria. IJAEDU- International E-Journal of Advances in Education, Vol. IV, Issue 10, April 2018, pp.61-67.

Hristov, N., Radulov, I., lliev, P., Andreeva, P. (2010a). Prioritization Methodology for Development of Required Operational Capabilities. RTO-MP-SAS-081, 2010.

Hristov, Neno. (2018b). NATO Resilience, Deter and Professional Military Education. Proceedings of INTCESS 2018- 5th International Conference on Education and Social Sciences 5-7 February 2018Istanbul, Turkey, pp. 183-186.

Hristov, N, Ninov, M. (2018c). People's Character As a Prerequisite for the Albanian 'National Delay'. // 5th International Conference on Education, Social Sciences and Humanities, 2-4 July, 2018, ISBN: 978605-82433-3-0 316, pp.316-323.

Hristov, N, Naplatanova, G. (2018d). The Stereotypes of Military Towards Journalists and Work with Embedded Reporters in Missions and Operations Abroad. // 5th International Conference on Education, Social Sciences and Humanities, 2-4 July, 2018 - Dubai, ISBN: 978-605-82433-3-0, pp. 293-315.

Hristov, Neno. (2017a). Bulgarian Experience in the Development of Military Concepts. // IJASOSInternational E-Journal of Advances in Social Sciences, Vol. III, Issue 9, December 2017, pp. 9981004.

Hristov, N., Georgiev, M. (2017b). Offset implementation impact on technology transfer in Bulgaria. // International Scientific Journal "Internauka". Izdatel' OOO «Finansovaya Rada Ukrainy», Kiyev, № 10 (32), 2017, pp. 110 -113, ISSN 2520-2057 (Hristov, N., Georgiev, M. Offset implementation impact on technology transfer in Bulgaria. // International Scientific Journal "Internauka". Издатель ООО «Финансовая Рада Украины», Киев, № 10 (32), 2017, pp. 110 -113, ISSN 2520-2057).

Hristov, N., Georgiev, M. (2017c). Offset as an economic operation and a trade practice. // International Scientific Journal "Internauka”. Izdatel' OOO «Finansovaya Rada Ukrainy», Kiyev, № 10 (32), 2017, pp. 114-117, ISSN 2520-2057 (Hristov, N., Georgiev, M. Offset as an economic operation and a trade practice. // International Scientific Journal "Internauka". Издатель ООО «Финансовая Рада Украины», Киев, № 10 (32), 2017, pp. 114-117, ISSN 2520-2057).

Hristov, N., Glushkov, P. (2018e). Comparative Analysis of the Management Activity Training Of the Cadets, Studying in the Logistic Specializations. // Proceedings of INTCESS2018- 5th International Conference on Education and Social Sciences 5-7 February 2018- Istanbul, Turkey, pp.582-588.

Hristov, N., Glushkov, P. (2018f). Some Aspects Regarding the Display of the Organizational Activity at Work of the Logistic Officers. // Proceedings of INTCESS2018- 5th International Conference on Education and Social Sciences 5-7 February 2018- Istanbul, Turkey, pp.187-193.

Hristov, Neno. (2017d). Policy for Implementation of the Enterprise Architecture as a Tool in Bulgarian Mod. // The University of Sydney, 'History, Problems and Prospects of Development of Modern Civilization' The XX International Academic Congress (Australia, Sydney, 18-20 July 2017) Papers and commentaries Volume XX, ISBN: 978-0-578-84563-7, pp. 821-829.

Madanski, V., Georgiev, M. (2017e). The offset as a specific sort of economic activity. // Scientific journal «Economics and finance». Academic publishing house of the Agricultural University, Priority research areas: Collection of scientific articles, 2017, pp. 4-13, ISBN 978-617-7214-53-2.

Madanski, V., Georgiev, M. (2017f). Study of the effect of offset implementation on technology transfer in the Republic of Bulgaria. // Scientific journal «Economics and finance». Academic publishing house of the Agricultural University, Priority research areas: Collection of scientific articles, 2017, pp. 43-51, ISBN 978-617-7214-53-2.

Terziev, V., Madanski, V., Georgiev, M. (2017g). Offset as an economic operation and a trade practice. // Proceedings of ADVED 2017- 3rd International Conference on Advances in Education and Social Sciences 9-11 October 2017- Istanbul, Turkey. International Organization Center of Academic Research, www.ocerint.org, 2017, pp. 748-753, ISBN: 978-605-82433-0-9.

Terziev, V., Madanski, V., Georgiev, M. (2017h). Offset implementation impact on technology transfer in Bulgaria. // Proceedings of ADVED 2017- 3rd International Conference on Advances in Education and Social Sciences 9-11 October 2017- Istanbul, Turkey .International Organization Center of Academic 
Research, www.ocerint.org, 2017, pp. 743-747, ISBN: 978-605-82433-0-9.

Terziev, V., Madanski, V., Georgiev, M. (2017i). Offset implementation impact on technology transfer in Bulgaria. // IJAEDU- International E-Journal of Advances in Education, International Organization Center of Academic Research, www.ocerint.org, 3, 2017, N 9, pp. 923-927, e-ISSN: 2411-18.

Terziev, V., Madanski, V., Georgiev, M. (2017j). Offset as an economic operation and a trade practice. // IJAEDU- International E-Journal of Advances in Education, International Organization Center of Academic Research, www.ocerint.org, 3, 2017, N 9, pp. 1051-1055, e-ISSN: 2411-18.

Terziev, V., Nichev, N., Bankov, S. (2016a). Corruption and national security. // Mezhdunarodnyy nauchnnyy zhurnal Inovatsionnaya nauka, №10-3/2016, Chastyakh 3, Ufa, Rossiya, ISSN 2410-6070, s.189-196 (Terziev, V., Nichev, N., Bankov, S. Corruption and national security. // Международный научнный журнал Иновационная наука, №10-3/2016, Частях 3, Уфра, Россия, ISSN 2410-6070, с.189-196).

Terziev, V., Nichev, N., Bankov, S. (2016b). Essence and reasons for the manifestation and basic areas of corruption and government structures for corruption counteraction in Bulgaria. // Sbornik nauchnykh trudov „Novyy vzglyad”: Mezhdunarodnyy nauchnyy vestnik: sbornik nauchnykh trudov. Vypusk 15 / Pod obshch. red. S.S. Chernova. - Novosibirsk: Izdatel'stvo TSRNS, 2016. - 166 s., ISBN 978-500068-714-7, s.116-134 (Terziev, V., Nichev, N., Bankov, S. Essence and reasons for the manifestation and basic areas of corruption and government structures for corruption counteraction in Bulgaria. // Сборник научных трудов „Новый взгляд”: Международный научный вестник: сборник научных трудов. Выпуск 15 / Под общ. ред. С.С. Чернова. - Новосибирск: Издательство ЦРНС, 2016. - 166 с., ISBN 978-5-00068-714-7, с.116-134).

Terziev, V., Nichev, N., Bankov, S. (2016c). National security of the republic of Bulgaria. // Science and practice: Collection of scientific articles. Thoroe-Bowker, Melbourne, Australia, 2016, ISBN 978-09942661-3-2, pp.12-21.

Terziev, V., Nichev, N., Bankov, S. (2016d). Tipichni modeli na razsledvanena koruptsiyata sred politseyski sluzhiteli. // Sbornik dokladi: Godishna universitetska nauchna konferentsiya, 20-21 oktomvri 2016 g., NVU „Vasil Levski“ - Veliko Tarnovo., Nauchno napravlenie „Sotsialni, stopanski i pravni nauki“, 7, 2016, ISSN 1314-1937, str.119-128 (Терзиев, В., Ничев, Н., Банков, С. Типични модели на разследванена корупцията сред полицейски служители. // Сборник доклади: Годишна университетска научна конференция, 20-21 октомври 2016 г., НВУ „Васил Левски“ - Велико Търново., Научно направление „Социални, стопански и правни науки“, 7, 2016, ISSN 1314-1937, стр.119-128).

Terziev, V., Nichev, N., Bankov, S. (2016e). Nakazatelno pravni aspekti na koruptsiyata i ustanoveni praktiki v Balgariya. // Sbornik dokladi: Godishna universitetska nauchna konferentsiya, 20-21 oktomvri 2016 g., NVU „Vasil Levski“ - Veliko Tarnovo., Nauchno napravlenie „Sotsialni, stopanski i pravni nauki“, 7 , 2016, ISSN 1314-1937, str.129-146 (Терзиев, В., Ничев, Н., Банков, С. Наказателно правни аспекти на корупцията и установени практики в България. // Сборник доклади: Годишна университетска научна конференция, 20-21 октомври 2016 г., НВУ „Васил Левски“ - Велико Търново., Научно направление „Социални, стопански и правни науки“, 7, 2016, ISSN 1314-1937, стр.129-146).

Terziev, V., Nichev, N., Bankov, S. (2016f). Prilozhenie na efektivna metodika na razsledvane na koruptsiyata sred politseyskite sluzhiteli v Balgariya. // Godishnik na NVU „Vasil Levski“, NVU „Vasil Levski“- Veliko Tarnovo, Izdatelski kompleks na NVU „Vasil Levski”, 2015, ISSN 1312-6148, str.144185 (Терзиев, В., Ничев, Н., Банков, С. Приложение на ефективна методика на разследване на корупцията сред полицейските служители в България. // Годишник на НВУ „Васил Левски“, НВУ „Васил Левски“- Велико Търново, Издателски комплекс на НВУ „Васил Левски”, 2015, ISSN 1312-6148, стр.144-185).

Terziev, V., Nichev, N., Bankov, S. (2016g). Razrabotvane na metodika na razsledvane na koruptsiyata sred politseyskite sluzhiteli v Balgariya. // XI Mezhdunarodnoy nauchnoy konferentsii „Innovatsii v tehnologiyah i obrazovanii“, 18-19 Marta 2016 g., Sbornik statey: chasty 3, Belovo- Veliko-tayrnovo, 2016, Kuzbasskiy gosudarstvennayy tehnicheskiy universitet imeni T.F. Gorbacheva Velikotayrnovskiy universitet im. Svyatayh. Kirilla i Mefodiya Filial KuzGTU v g. Belovo Vaysshaya shkola agrobiznesa i razvitiya regionov, Plovdiv, 2016, s.413-422, ISBN 978-5-906888-03-7 (Терзиев, В., Ничев, Н., Банков, С. Разработване на методика на разследване на корупцията сред полицейските служители в България. // XI Международной научной конференции „Инновации в технологиях и образовании“, 18-19 Марта 2016 г., Сборник статей: часть 3, Белово- Велико-тырново, 2016, 
Кузбасский государственный технический университет имени Т.Ф. Горбачева Великотырновский университет им. Святых. Кирилла и Мефодия Филиал КузГТУ в г. Белово Высшая школа агробизнеса и развития регионов, Пловдив, 2016, с.413-422, ISBN 978-5-906888-03-7).

Terziev, V., Nichev, N., Bankov, S. (2016h). Prilozhenie na efektivna metodika na razsledvane na koruptsiyata sred politseyskite sluzhiteli v Balgariya. // Sbornik dokladi: Parva nauchna konferentsiya po sotsialno predpriemachestvo. Saveti, umeniya i instrumenti za konsultirane na sotsialnite predpriemachi, Proekt : Umeniya za biznes konsultanti v oblastta na sotsialnoto predpriemachestvo, International scientific conference 29 September 2016, Plovdiv, Bulgaria, Agraren Universitet Plovdiv, 2016, ISBN 978-954-517-249-6 (CD), ISBN 978-954-517-250-2 (Print), str.177-204 (Терзиев, В., Ничев, Н., Банков, С. Приложение на ефективна методика на разследване на корупцията сред полицейските служители в България. // Сборник доклади: Първа научна конференция по социално предприемачество. Съвети, умения и инструменти за консултиране на социалните предприемачи, Проект : Умения за бизнес консултанти в областта на социалното предприемачество, International scientific conference 29 September 2016, Plovdiv, Bulgaria, Аграрен Университет Пловдив, 2016, ISBN 978-954-517-249-6 (CD), ISBN 978-954-517-250-2 (Print), стр.177-204).

Nichev, N. (2017k). Ofsetna politika na stranite ot Evropeyskiya Sayuz. Spisanie za nauka „Novo znanie”, Akademichno izdatelstvo „Talant“, Visshe uchilishte po agrobiznes i razvitie na regionite, Plovdiv, Vol 6, No 1, 2017, str. 121-128, ISSN 2367-4598 (Online), ISSN 1314-5703 (Print) (Ничев, Н. Офрсетна политика на страните от Европейския Съюз. Списание за наука „Ново знание”, Академично издателство „Талант“, Висше училище по агробизнес и развитие на регионите, Пловдив, Vol 6, No 1, 2017, стр. 121-128, (Online) ISSN 2367-4598, (Print) ISSN 1314-5703).

Nichev, N. (2017l). Perspektivi za izpolzvane na ofsetnite sdelki. Spisanie za nauka "Novo znanie”, Akademichno izdatelstvo „Talant“, Visshe uchilishte po agrobiznes i razvitie na regionite - Plovdiv, Vol 6, No 1, 2017: pp. 129-135, (Online) ISSN 2367-4598, (Print) ISSN 1314-5703 (Ничев, Н. Перспективи за използване на офсетните сделки. Списание за наука „Ново знание”, Академично издателство „Талант“, Висше училище по агробизнес и развитие на регионите Пловдив, Vol 6, No 1, 2017: pp. 129-135, (Online) ISSN 2367-4598, (Print) ISSN 1314-5703).

Kanev, D.,Terziev. V. (2017m). Behavioral economics: development, condition and perspectives. // IJASOSInternational E-Journal of Advances in Social Sciences, Vol. III, Issue 8, e-ISSN: 2411-183X.

Kanev, D.,Terziev. V. (2017n). Behavioral economics: development, condition and perspectives. // Proceedings of SOCIOINT 2017- 4th International Conference on Education, Social Sciences and Humanities 10-12 July 2017- Dubai, UAE, ISBN: 978-605-82433-1-6.

Sotirov, B., Terziev, V. (2015a). Predizvikatelstva i perspektivi pred obuchenieto po tehnologichni distsiplini. // Parva mezhdunarodna nauchna konferentsiya „Predizvikatelstva pred savremennite organizatsii, svarzani s postigane na ustoychivost - znanie i inovatsii v upravlenieto i funktsioniraneto",Plovdiv. ISBN 978-619-7246-04-9 (DVD), ISBN 978-619-7246-06-3 (e-book).

Sotirov, B., Terziev, V. (2015b). Challenges and perspectives to the training in technological subjects. // Book of Abstracts: First International Scientific Conference "Sustainability Challenges in Modern Organizations - Knowledge \& Innovation in Management \& Operation", ISBN 978-619-7246-03-2 (DVD), ISBN 978-619-7246-05-6 (e-book).

Terziev. V. (20170). National security of the republic of Bulgaria. // The Chinese Journal of International Politics, №1(10), ISSN 1750-8916.

Terziev. V. (2016i). Human resource management systems in security and defense: social policies for social activities. // XXXII Mezhdunarodnaya nauchno-prakticheskaya konferentsiya, Evraziyskiy soyuz uchenayh (ESU), Ezhemesyachnayy nauchnayy zhurnal № 12 (33)/ 2016 Chasty 1, Moskva 30.12.2016g., ISSN 2411-6467.

Terziev. V. (2017p). Entry Opportunities in the Bulgarian Military - Educational System and Ensuring of Civil Rights. // 3rd Central and Eastern European LUMEN International Scientific Conference New Approaches in Social and Humanistic Sciences 8-10 June 2017 | Chisinau, Republic of Moldova, ISBN: 978-973-166-461-3.

Terziev. V. (2017q). National security of the republic of Bulgaria. // International Journal of Management and Applied Science, Volume-3, Issue-4, ISSN: 2394-7926.

Terziev, V., Vezieva. V., Arabska, A. (2016j). Balgarskite universiteti i vazmozhnostite na Operativna 
programa „Nauka i obrazovanie za inteligenten rastezh". // Mezhdunarodna nauchna konferentsiya „Obrazovanie, nauka, ikonomika i tehnologii“ 23-24 yuni 2016 g. Akademichno spisanie „Upravlenie i obrazovanie“ Tom XII(1) 2016, ISSN 1312-6121.

Terziev, V., Manolov.D. (2016k). Sazdavane na dobra organizatsionna sreda za nauchnoizsledovatelska deynost (Creation of good organizational environment for scientific research activity), Aktual'nyye problemy globalizatsii. // Saloniki, Gretsiya (Actual problems of globalization, August 29, 2016, Thessaloniki, Greece), Scientific journal „ECONOMICS AND FINANCE“, Actual problems of globalization - Collection of scientific articles, ISBN 978-617-7214-34-1.

Terziev, V., Minev, R., Sotirov, B., Ivanov, K. (2016l). Vazmozhnosti za izgrazhdane na tsentar za kompetentnost $v$ Severen tsentralen rayon na Republika Balgariya. // Godishna universitetska nauchna konferentsiya, 20-21 oktomvri 2016 g. NVU „Vasil Levski“- Veliko Tarnovo. Sbornik dokladi tom 2, Nauchni napravleniya „Prirodomatematicheski nauki” i „Tehnicheski nauki”, ISSN 1314-1937.

Terziev. V., Kanev, D. (2017r). Education and Behavioural Failures. // Proceedings of ADVED 2017- 3rd International Conference on Advances in Education and Social Sciences 9-11 October 2017- Istanbul, Turkey, ISBN: 978-605-82433-0-9.

Terziev, V, Madanski, V. (2017s). Development of military education system in Bulgaria (Razvitie na voennoobrazovatelnata sistema $v$ Balgariya). // Topical questions of contemporary science, United States of America 2017, ISBN 978-0-9988732-1-3.

Terziev, V, Madanski, V. (2017t). Guidelines for development of military education system in Bulgaria (Nasoki za razvitie na voennoobrazovatelnata sistema na Balgariya). // Topical questions of contemporary science, United States of America 2017, ISBN 978-0-9988732-1-3.

Terziev, V, Madanski, V. (2017u). Guidelines for development of military education system in Bulgaria. // Proceedings of the VII International Academic Congress "Fundamental and Applied Studies in EU and CIS Countries” (United Kingdom, Cambridge, England, 26-28 February 2017). Volume VII. Cambridge University Press, 2017, ISBN: 978-0-875-83597-4.

Terziev, V, Madanski, V., Kanev, D. (2017v). Entry opportunities in the bulgarian military-educational system and ensuring of civil rights. // Proceedings of SOCIOINT 2017- 4th International Conference on Education, Social Sciences and Humanities 10-12 July 2017- Dubai, UAE, ISBN: 978-605-82433-1-6.

Terziev, V, Madanski, V., Kanev, D. (2017w). Entry opportunities in the bulgarian military-educational system and ensuring of civil rights. // IJAEDU- International E-Journal of Advances in Education, Vol. 3, Issue 8, August 2017, e-ISSN:2411-1821.

Terziev, V, Madanski, V., Kanev, D. (2017x). Entry opportunities in the Bulgarian military-educational system. // Sport, Education and Society, Issue 8 (2), Volume 22. Taylor \& Francis, Print ISSN: 1357-3322 Online ISSN: $1470-1243$.

Terziev, V, Madanski, V., Kanev, D. (2017y). Condition and capabilities of the military-educational system of the Republic of Bulgaria. // Sport, Education and Society, Issue 8 (2), Volume 22. Taylor \& Francis, Print ISSN: 1357-3322 Online ISSN: 1470-1243.

Terziev, V, Madanski, V., Kanev, D. (2017z). Directions for improvement of the military-educational system and its contribution for strengthening national security and the defence of the country. // Sport, Education and Society, Issue 8 (2), Volume 22. Taylor \& Francis, Print ISSN: 1357-3322 Online ISSN: 1470-1243.

Terziev, V., N.Nichev. (2016m). Ikonomicheski harakteristiki na ofestnite sdelki s otrbranitelni produkti. // Scientific journal „Economics and Finance”, Problems of development modern science: Theory and practice - Collection of scienfic articles, pp.101-106.

Terziev. V., N.Nichev. (2017). Osnovni harakteristiki na kompensaciite v tyrgoviqta s otbrana. // Proceedings of SOCIOINT 2017- 4th International Conference on Education, Social Sciences and Humanities, pp.661-666. 